\title{
Variability in the Light Absorption Coefficient by Phytoplankton, Non-Algal Particles and Colored Dissolved Organic Matter in the Northern Gulf of California
}

\author{
Stella P. Betancur-Turizo1,2, Adriana G. González-Silvera ${ }^{*}$, Eduardo Santamaría-Del-Ángel1, \\ Roberto Millán-Núñez ${ }^{1}$, Eduardo Millán-Núñez ${ }^{3}$, Héctor García-Nava ${ }^{4}$, Víctor M. Godínez ${ }^{5}$, \\ Laura Sánchez-Velasco6 \\ ${ }^{1}$ Facultad de Ciencias Marinas, Universidad Autónoma de Baja California, Ensenada, México \\ ${ }^{2}$ Grupo de Investigación en Oceanología, Facultad de Oceanografía Física, Escuela Naval de Cadetes “Almirante Padilla”, Barrio \\ Bosque, Sector Manzanillo, Cartagena de Indias, Colombia \\ ${ }^{3}$ Departamento de Ecología Marina, CICESE, Ensenada, México \\ ${ }^{4}$ Instituto de Investigaciones Oceanológicas, Universidad Autónoma de Baja California, Ensenada, México \\ ${ }^{5}$ Departamento de Oceanografía Física, CICESE, Ensenada, México \\ ${ }^{6}$ Departamento de Plancton y Ecología Marina, CICIMAR-IPN. Av. Instituto Politécnico Nacional s/n, La Paz, México \\ Email: *adriana.gonzalez@uabc.edu.mx
}

How to cite this paper: Betancur-Turizo, S.P., González-Silvera, A.G., SantamaríaDel-Ángel, E., Millán-Núñez, R., MillánNúñez, E., García-Nava, H., Godínez, V.M. and Sánchez-Velasco, L. (2018) Variability in the Light Absorption Coefficient by Phytoplankton, Non-Algal Particles and Colored Dissolved Organic Matter in the Northern Gulf of California. Open Journal of Marine Science, 8, 20-37.

https://doi.org/10.4236/ojms.2018.81002

Received: November 10, 2017

Accepted: December 22, 2017

Published: December 25, 2017

Copyright $\odot 2018$ by authors and Scientific Research Publishing Inc. This work is licensed under the Creative Commons Attribution International License (CC BY 4.0).

http://creativecommons.org/licenses/by/4.0/

\section{(c) (i) Open Access}

\begin{abstract}
Variability of the optical properties of the northern Gulf of California (México) were analyzed for the first time based on six cruises performed from spring to summer (March to September) between 2008 and 2013. The changes observed in the absorption by three seawater components (phytoplankton, detritus and chromophoric dissolved organic matter or CDOM) were analyzed in relation to changes in bio-optical regions and composition of the phytoplankton community (determined based on phytoplankton pigments). Two regions with unique bio-optical characteristics were identified separated by a narrow transition zone: the Upper Gulf of California (UGC) and Northern Gulf of California (NGC). Despite the temporal changes in their spatial distribution they maintained particular characteristic. UGC is characterized by an average Chla of $1.78 \mathrm{mg} / \mathrm{m}^{3}$, the dominance of microphytoplankton (diatoms and dinoflagellates) and a stronger contribution of detritus to total light absorption. NGC is characterized by an average Chla of $0.7 \mathrm{mg} / \mathrm{m}^{3}$ and the predominance of picophytoplankton, characterized by the dominance of zeaxanthin (marker pigment for cyanobacteria) and/or chlorophyll b (marker pigment for green algae), along with a co-dominium by CDOM and phytoplankton to light absorption. Results indicate that Case II waters can be very
\end{abstract}


different when evaluating the individual contribution by phytoplankton, detritus and CDOM to total light absorption what has to be considered for the selection of bio-optical models for each specific region what can also help to a better definition of the related uncertainties.

\section{Keywords}

Light Absorption, Phytoplankton, CDOM, Detritus, Ocean Color, Gulf of California

\section{Introduction}

The study of the optical properties of the ocean has raised increasing interest in the last decades, leading to the development of technological tools to estimate these properties through remote sensing [1] [2] [3]. However, these tools have been validated for Case-I waters [4], which do not represent the conditions of coastal areas characterized by being optically complex (Case II) and that concentrate the main economic and productive activities in many countries. Thus, when investigating the optical complexity of these areas, the following questions should be addressed: What do we know about the optical properties of the major components of sea water, and how can we quantify them? [5]. It is currently known that coastal areas receive contributions of particulate and dissolved material from various sources, the optical properties of which can be determined through remote sensing. However, the quality and reliability of the data obtained require an accurate characterization of these properties [6]. Bio-optical models [7] [8] [9] [10] have been proposed for estimating these optical properties; however, these models are not always highly accurate, particularly in coastal areas, since the optical properties of these water bodies do not depend exclusively on phytoplankton [11], except when there are high-intensity events such as phytoplankton blooms.

Bio-optical models group the components of the open ocean into two main categories: phytoplankton and detritus, the latter including the combined signal of Chromophoric Dissolved Organic Matter (CDOM, see Table 1 for symbols and abbreviations used in this paper) and non-algal (organic and inorganic) particles [6]. These components influence the absorption and light-scattering properties of water and vary according to biochemical (algal blooms, wastewater discharges) and hydrodynamic (tidal currents, coastal fronts, turbulence) processes that are characteristic of the ecosystem. Each component has particular characteristics; for example, CDOM absorbs UV and visible light, and is considered as the primary driver of the optical properties in coastal areas and freshwater [11] [12] [13], a reason for which it has been widely studied in the last decade [12] [13]. Its magnitude and spectral form depend on its origin, which can be derived from the decomposition of woody plants in terrestrial environments (allochthonous) or from the decomposition of algae and aquatic vegetation within a 
Table 1. Symbol and abbreviations.

\begin{tabular}{ccc}
\hline Symbol/Abbreviation & Description & Unit \\
\hline$\lambda$ & Wavelength & $\mathrm{nm}$ \\
CDOM & Chromophoric Dissolved Organic Matter & \\
UGC & Upper Gulf of California & \\
NGC & Northern Gulf of California & \\
Chla & Chlorophyll a & $\mathrm{mg} / \mathrm{m}^{3}$ \\
$\mathrm{~K}_{\mathrm{d}}$ & Light attenuation coefficient & $\mathrm{m}^{-1}$ \\
$1 \mathrm{OD}$ & first optical depth & $\mathrm{m}$ \\
$\mathrm{OD}$ & Optical density & \\
$\mathrm{a}_{\mathrm{p}}(\lambda)$ & Particulate absorption coefficient & $\mathrm{m}^{-1}$ \\
$\mathrm{a}_{\mathrm{d}}(\lambda)$ & Non-Algal Particle (or detrital) absorption coefficient & $\mathrm{m}^{-1}$ \\
$\mathrm{a}_{\mathrm{ph}}(\lambda)$ & Phytoplankton absorption coefficient & $\mathrm{m}^{-1}$ \\
$\mathrm{a}_{\mathrm{CDOM}}(\lambda)$ & CDOM absorption coefficient & $\mathrm{m}^{-1}$ \\
\hline
\end{tabular}

water body (autochthonous) [14]. On the other hand, detritus, or non-algal particulate matter (bacteria, inorganic minerals and bubbles) [15], is characterized by a greater absorption of blue light, which decreases exponentially toward the red portion of the spectrum. Finally, absorption by phytoplankton is more or less directly related to chlorophyll a concentration [15], with spectral variations similar to those of any absorption spectrum of an individual pigment, but in general exhibits absorption peaks in the blue and red spectral regions due to the ubiquitous presence of chlorophyll a [16].

The Northern Gulf of California is a water body with a high optical complexity that has been classified as Case II [17] [18]. Its particular optical characteristics are partly due to the high light scattering due to suspended material [17], the level of which may be very high, mainly in shallow areas, as a result of strong tidal currents [19]. The region is also affected by a seasonally reversible circulation, with a gyre in the center of the basin and a coastal current running on the continental shelf [20]. This process, in addition to tidal mixing, leads to high primary productivity and biological diversity in this region, which in turn favors a high abundance of commercially and ecologically important fish species [21] [22].

Few studies have reported the variability of the optical properties in this area, except for the works of Millán-Núñez et al. [23], Pegau et al. [17] and BastidasSalamanca et al. [18]. The first described the spatial and vertical variations of the light absorption coefficient that characterized phytoplankton and phytoplankton pigments recorded in a single cruise that included five stations distributed across the Gulf of California, only one being located to the northern region. In the second, the cruises focused on the central region of the Gulf, with a few stations located to the northeast. In the third, the results were derived from the analysis 
of a single cruise, which while contributing to the knowledge of these properties, did not investigate aspects such as the seasonal and inter-annual variability in the region and the variability in the absorption coefficients of particulate material (phytoplankton and detritus) compared with CDOM. This latter variable has not been evaluated previously in this region; however, it is very important to be considered to contribute to the global bio-optical models [24] and due to its role in cycling carbon, trace elements, and trace gases of importance to biological activity and global climate [12] [13] [25].

In this context, the primary objective of this study was to document for the first time the spatial and temporal variability of the absorption coefficients of phytoplankton, detritus and CDOM to the north of the Gulf of California using a database that includes six oceanographic cruises from spring to summer (March to September) between 2008 and 2013. In addition, the absorption budget associated to the study area was analyzed to give elements to both evaluate bio-optical models in optically complex waters and propose new approaches specific for this region.

\section{Methods}

\subsection{Study Area}

The study area comprises the northern part of the Gulf of California, México and is located at $30.5^{\circ} \mathrm{N}$ to $32^{\circ} \mathrm{N}$ and $-115^{\circ} \mathrm{W}$ to $-113.5^{\circ} \mathrm{W}$ (Figure 1). It includes the Upper Gulf of California (UGC) and part of the Northern Gulf of California (NGC) oceanographic provinces (Figure 1) [26]. The area is shallow, with depths of less than $30 \mathrm{~m}$ in UGC and less than $200 \mathrm{~m}$ in NGC (Figure 1). The mean temperature varies seasonally between approximately $14^{\circ} \mathrm{C}$ in winter and over $32^{\circ} \mathrm{C}$ in summer [27] [28] [29]. Salinity ranges between 35.4 in NGC open waters and 39 in UGC shallow areas [27] [30] [31]. The tide is mainly semi-diurnal, with a range of approximately $6 \mathrm{~m}$ during spring tides, where there is the observation of strong tidal currents of up to $1 \mathrm{~m} / \mathrm{s}$, and a tidal mixing front that separates the well-mixed UGC waters from the deeper and stratified NGC waters [19].

\subsection{Data and Methods}

\subsubsection{Field Sampling}

Physical and biological data were recorded during six oceanographic cruises in the study area performed during neap tides. Figure 2 indicates the sampling dates and the number of stations included in each cruise.

Water transparency was measured using a Secchi disk. It is known that this measurement can be affected by human eye but during cruises we minimized this error making measurements by the same person and at the same time interval (between 10 am to $3 \mathrm{pm}$ ). In addition, we only used data taken during mostly sunny days, when we could assume that there is more direct light than diffuse light penetrating into the water column (see Santamaria-del-Angel et al. [32] for 


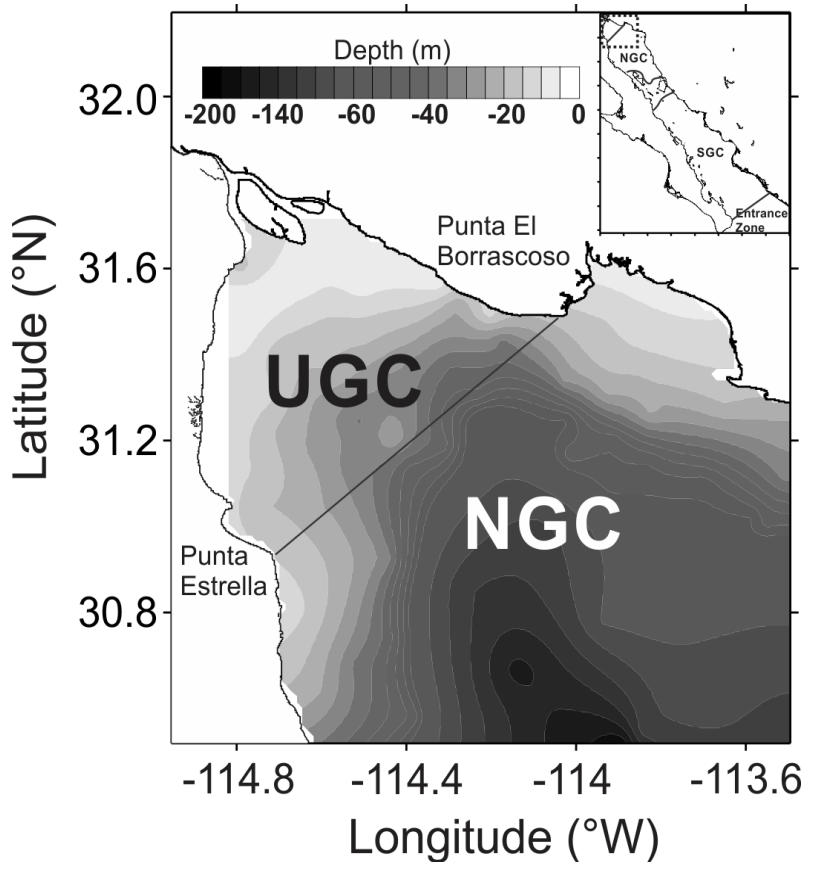

Figure 1. Bathymetry of the study area with the UGC and part of the NGC oceanographic regions. Inset: The oceanographic provinces defined by Lavín and Marinone [26].
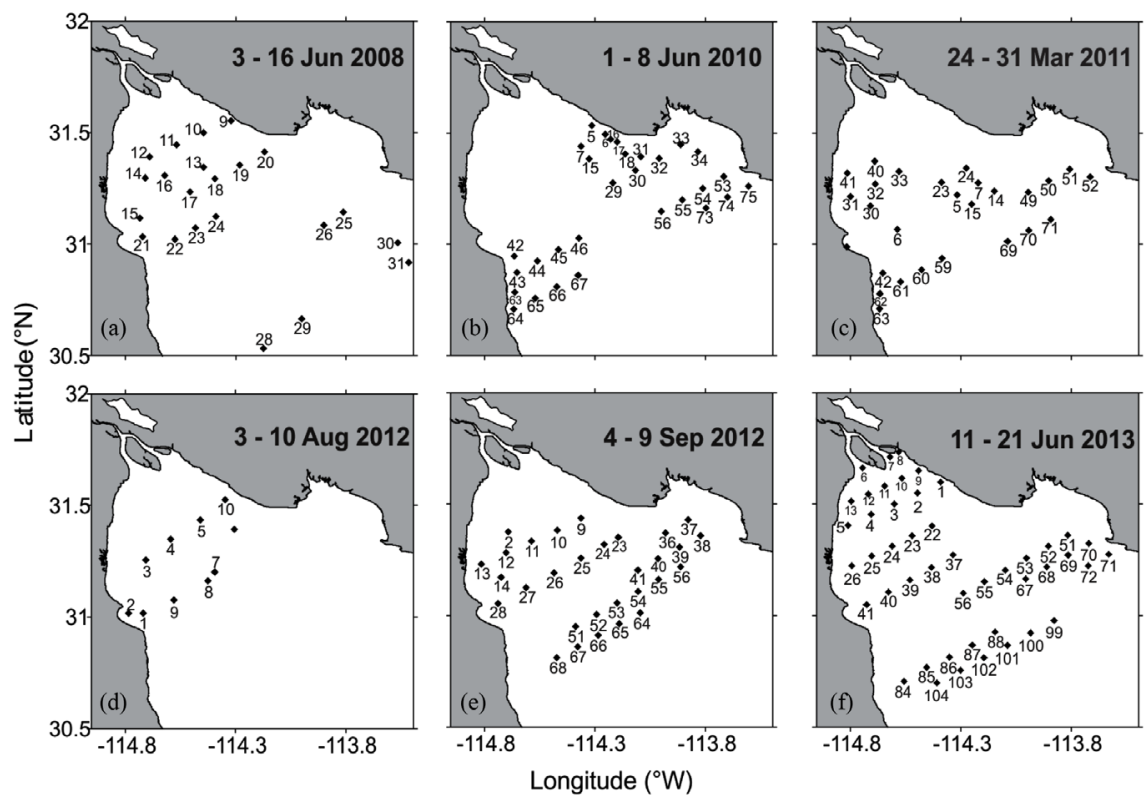

Figure 2. Grid of stations in each cruise. The stations sampled in the cruises conducted during the study period are shown as follows: (a) June 2008; (b) June 2010; (c) March 2011; (d) August 2012; (e) September 2012; and (f) June 2013.

a detailed description of these assumptions). In doing that we assumed that errors were consistent (or constant) and they did not affect the comparison among stations and cruises. From Secchi disk it was calculated the light attenuation coefficient $\left(K_{d}\right)$ and the first optical depth (1OD) as $1 O D=1 / K_{d}[33]$. 
Surface water samples ( $0.50 \mathrm{~m}$ depth) were collected using $5 \mathrm{~L}$ Niskin bottles for the determination of photosynthetic pigments and light absorption coefficients of particulate material and CDOM. A sample was taken directly from the Niskin bottle using previously washed amber glass flasks for the determination of the CDOM absorption coefficient [34]. From the remaining water, 1 to 2 liters were filtered through a positive filtration system using $25 \mathrm{~mm}$ Whatman GF/F filters for the analysis of pigments in phytoplankton [35] [36], and of the light absorption coefficient for particulate material [34].

\subsubsection{Determination of Absorption Coefficients}

The light absorption coefficient for particulate material $\left(a_{p}(\lambda)\right)$ was determined through the methodology of Mitchell et al. [34]. For June 2008, June 2010 and March 2011, the optical density (OD) was read in a Perkin-Elmer Lambda 10 spectrophotometer with integrating sphere. For August 2012, September 2012 and June 2013, a Cary 100 UV-Vis spectrophotometer with integrating sphere was used. For all cruises, the absorption coefficients for particulate material $a_{p}(\lambda)$ and detritus $a_{d}(\lambda)$ were determined as [34]:

$$
a_{p}(\lambda)=\left(2.3003 \frac{S}{V}\right)\left(C_{1}\left(O D_{f}-O D_{\text {null }}\right)+C_{2}\left(O D_{f}-O D_{\text {null }}\right)^{2}\right)
$$

where $O D_{f}$ is the optical density of the filter with material, $O D_{\text {null }}$ is the correction for residual shifts in the filter (the mean between $790-800 \mathrm{~nm}$ was used), $S$ is the effective filtration area, $V$ is the volume filtered, and $\mathrm{C}_{1}$ and $\mathrm{C}_{2}$ are the correction coefficients for the increase in length of the trajectory caused by the multiple scattering in the fiberglass filter; values of 0.392 and 0.655 , respectively, were used in this case [34].

The absorption coefficient of phytoplankton $\left(a_{p h}(\lambda)\right)$ was determined as the difference between the absorption coefficient of the total particulate material $a_{p}(\lambda)$ and the one for detritus $a_{d}(\lambda)$. Water samples for CDOM absorption measurements were collected only during March 2011, August and September 2012 and June 2013. The absorption coefficient for $\operatorname{CDOM}\left(a_{\mathrm{CDOM}}(\lambda)\right)$ was calculated as [34]:

$$
a_{\text {CDOM }}(\lambda)=\left(\frac{2.303}{L}\right)\left(\left(O D_{S}(\lambda)-O D_{\text {null }}\right)-\left(O D_{b}(\lambda)-O D_{\text {null }}\right)\right)
$$

where $l$ is the cell path length $(10 \mathrm{~cm}), O D_{s}$ is the optical density of the sample, $O D_{b}$ is the optical density of the blank, and $O D_{\text {null }}$ is the optical density at the null point $(600 \mathrm{~nm})$. Physical and biological data were recorded during six oceanographic cruises in the study area performed during neap tides. Figure 2 indicates the sampling dates and the number of stations included in each cruise.

\subsubsection{Determination of Photosynthetic Pigments}

Two methodologies were used for the pigment concentration analysis. For June 2008, June 2010 and March 2011, the methodology of Barlow et al. [35] was 

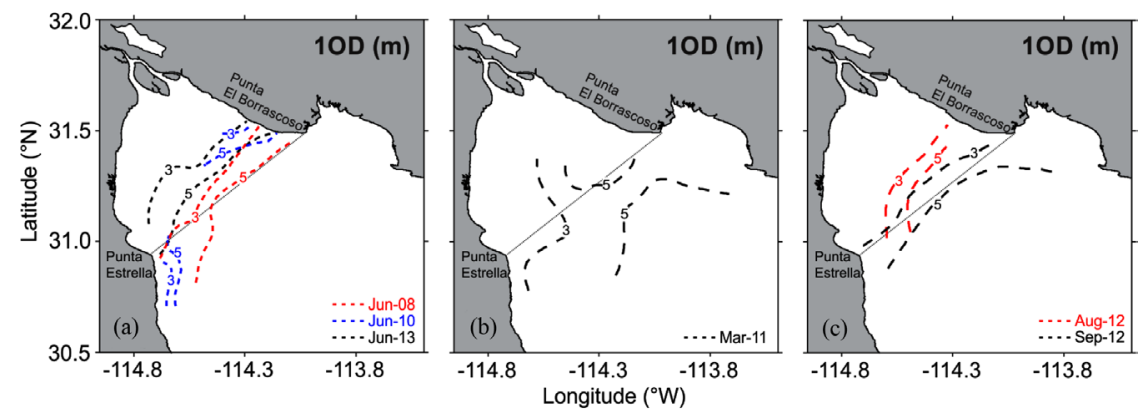

Figure 3. Bio-optical regions as defined according to the 1OD for (a) June 2008, June 2010 and June 2013; (b) March 2011; and (c) August and September 2012. Dotted lines indicate the position of the transition zone. As reference it is indicated the boundary between the UGC and NGC regions (gray line) established by Lavín and Marinone [26].

used; for August 2012 and June 2013, the methodology of Thomas [36]. There are no data on pigments for September 2012. The standard pigments used in the HPLC were purchased from Sigma-Aldrich and DHI (Denmark). The concentration of the standards was measured spectrophotometrically using published extinction coefficients [37]. Standard pigments were used for the identification of absorption peaks in the chromatogram.

\subsection{Bio-0ptical Regions and Statistical Analysis}

Lavin and Marinone [26] classified the study area according to physical processes in UGC and NGC and proposed an imaginary line between Punta Borrascoso and Punta Estrella (Figure 1) as the limit between them. BastidasSalamanca et al. [18] proposed the 1OD to classify these regions considering this variable as an indicator of water transparency that allow the evaluation of the dynamism of the frontier between a shallow UGC and a deeper NGC. In our study we classified the sampling stations using this criterion which considers that stations with $1 \mathrm{OD}<3 \mathrm{~m}$ belong to UGC, stations with $1 \mathrm{OD}>5 \mathrm{~m}$ correspond to NGC, and stations with 1OD between $3 \mathrm{~m}$ and $5 \mathrm{~m}$ belong to a transition zone. In order to establish if the differences between UGC and NGC were statistically significant, a priori non-parametric Kruskal-Wallis test [38] was used to assess the differences in the absorption coefficients $a_{p h}(\lambda), a_{d}(\lambda)$ and $a_{\mathrm{CDOM}}(\lambda)$. This test was applied based on the first empirical standardized orthogonal function (ZEOF1) combining the absorption coefficients by wavelength $(412,440,488,555$ and $675 \mathrm{~nm})$. When the null hypothesis was rejected, a posteriori multiple contrast Wilcoxon test for two independent samples was used to establish whether significant differences exist. In most contrasts the number of data was higher than ten, and the approach of $\mathrm{H}$ calculated values proposed by Kruskal-Wallis was used. These statistical tests were applied by cruise and also for the entire dataset. For cruises in 2008 and 2010 we only considered $a_{p h}(\lambda)$ and $a_{d}(\lambda)$ for these analyses. 


\section{Results}

\subsection{Bio-Optical Regions}

The differences between bio-optical regions were statistically significant ( $\alpha=$ 0.05 ) when evaluating each cruise individually or when the entire dataset was considered. Contrary of what was established as a static imaginary line [26] our data confirm that the transition zone has a dynamic behavior. For example, in June 2008 (Figure 3(a)) and September 2012 (Figure 3(c)), the transition zone was located in the position just mentioned; however, in March 2011 (Figure 3(b)) it shifted to southwest towards the Baja California peninsula. In contrast, in June 2010 (Figure 3(a)), August 2012 (Figure 3(c)) and June 2013 (Figure $3(a))$ the transition zone was located toward the shallowest UGC areas. A descriptive statistics for all variables analyzed in this work organized by region and cruise is presented in Table 2 .

\subsection{Variability of Water Optical Constituents}

UGC showed the largest ranges of variation for $a_{p h}(440)$ and $a_{d}(440)$ (Table 2). On most cruises the average values exceeded those reported for the NGC region, except for March 2011. In particular, the data for June of 2013 are worth noting, as $a_{d}(440)$ yielded the highest values of all cruises (Table 2). The coefficient $a_{\text {CDOM }}(440)$ showed average values between $0.098 \pm 0.036 \mathrm{~m}^{-1}$ and $0.194 \pm 0.078$ $\mathrm{m}^{-1}$, rising from March 2011 to June 2013, when the peak values were recorded despite the little variation.

NGC showed lower $a_{p h}(440), a_{d}(440)$ and $a_{\mathrm{CDOM}}(440)$ than UGC (Table 2). When $a_{\text {CDOM }}(440)$ average values are compared with the absorption coefficients $a_{p h}(440)$ and $a_{d}(440)$, it is evident that $a_{\mathrm{CDOM}}(440)$ show the highest peak values in the transition region and NGC (Table 2). Finally, variables from the transition zone presented a range of variability that is between that of the UGC and the NGC (Table 2), although $a_{\text {CDOM }}(440)$ was especially highly scattered across stations in March 2011, when the highest values of all cruises analyzed were observed (Table 2).

We compared the average values of $a_{p h}(440), a_{d}(440)$ and $a_{\text {CDOM }}(440)$ with data from other coastal regions (Figure 4), and it was observed that $a_{p h}(440)$ and $a_{\text {CDOM }}(440)$ in the UGC are lower while $a_{d}(440)$ values are higher and with a larger range of variability. For NGC values are in the same range or even lower than those averages, especially $a_{\mathrm{CDOM}}(440)$.

\subsection{Phytoplankton Pigments}

Chla showed important spatial and temporal variations, with a trend to higher concentrations in UGC vs. NGC. Chla ranged between $1.34 \pm 1.35$ and $2.26 \pm$ $1.22 \mathrm{mg} / \mathrm{m}^{3}$ in UGC, between $0.51 \pm 0.25$ and $2.19 \pm 2.16 \mathrm{mg} / \mathrm{m}^{3}$ in the transition zone and between $0.31 \pm 0.21$ and $1.37 \pm 0.63 \mathrm{mg} / \mathrm{m}^{3}$ in NGC (Table 2). Likewise, March 2011 showed the highest values and June 2010 the lowest (Table 2). 
Table 2. Number of data ( $\mathrm{n})$, range and mean \pm standard deviation for first optical depth (1OD), $\mathrm{a}_{\mathrm{ph}}(440), \mathrm{a}_{\mathrm{d}}(440), \mathrm{a}_{\mathrm{CDOM}}(440)$ and in-situ Chla $\left(\mathrm{mg} / \mathrm{m}^{3}\right)$ for the bio-optical regions defined for each cruise.

\begin{tabular}{|c|c|c|c|c|c|c|c|c|c|}
\hline \multirow{2}{*}{$\begin{array}{l}\text { Cruise/bio-optical } \\
\text { regions }\end{array}$} & \multicolumn{3}{|c|}{ UGC } & \multicolumn{3}{|c|}{ Transition Zone } & \multicolumn{3}{|c|}{ NGC } \\
\hline & $\mathrm{n}$ & Range & Mean \pm SD & $\mathrm{n}$ & Range & Mean \pm SD & $\mathrm{n}$ & Range & Mean \pm SD \\
\hline \multicolumn{10}{|l|}{$10 D(m)$} \\
\hline Jun-08 & 10 & $0.6-2.1$ & $1.4 \pm 0.5$ & 5 & $3.0-4.8$ & $3.9 \pm 0.7$ & 7 & $6.0-9.0$ & $7.1 \pm 1.1$ \\
\hline Jun-10 & 4 & $1.8-2.4$ & $2.0 \pm 0.3$ & 9 & $3.0-4.8$ & $4.2 \pm 0.7$ & 17 & $6.0-11.4$ & $8.4 \pm 1.7$ \\
\hline Mar-11 & 10 & $0.9-2.7$ & $1.8 \pm 0.6$ & 9 & $3.0-4.8$ & $3.9 \pm 0.7$ & 8 & $5.0-9.6$ & $6.5 \pm 1.6$ \\
\hline Aug-12 & 6 & $0.8-2.5$ & $1.3 \pm 0.6$ & 1 & 3.5 & 3.5 & 3 & $6.5-7.8$ & $6.9 \pm 0.8$ \\
\hline Sep-12 & 9 & $0.5-2.0$ & $1.2 \pm 0.5$ & 7 & $3.3-4.2$ & $3.8 \pm 0.3$ & 14 & $5.4-11.4$ & $8.2 \pm 1.8$ \\
\hline Jun-13 & 15 & $0.1-3.0$ & $0.7 \pm 0.9$ & 6 & $3.0-4.8$ & $4.1 \pm 0.8$ & 25 & $5.7-18.1$ & $10.4 \pm 3.4$ \\
\hline All cruises & 54 & $0.1-3.0$ & $1.3 \pm 0.8$ & 37 & $3.0-4.8$ & $4.0 \pm 0.6$ & 74 & $5.0-18.1$ & $8.7 \pm 2.7$ \\
\hline \multicolumn{10}{|l|}{$a_{p h}(440)\left(m^{-1}\right)$} \\
\hline Jun-08 & 7 & $0.037-0.161$ & $0.089 \pm 0.047$ & 3 & $0.063-0.091$ & $0.082 \pm 0.16$ & 5 & $0.032-0.081$ & $0.049 \pm 0.021$ \\
\hline Jun-10 & 4 & $0.021-0.056$ & $0.041 \pm 0.016$ & 7 & $0.012-0.052$ & $0.032 \pm 0.014$ & 16 & $0.006-0.041$ & $0.016 \pm 0.011$ \\
\hline Mar- 11 & 10 & $0.016-0.092$ & $0.042 \pm 0.028$ & 9 & $0.021-0.128$ & $0.057 \pm 0.034$ & 8 & $0.023-0.094$ & $0.053 \pm 0.029$ \\
\hline Aug-12 & 6 & $0.073-0.136$ & $0.098 \pm 0.022$ & 1 & 0.028 & 0.028 & 2 & $0.019-0.052$ & $0.036 \pm 0.023$ \\
\hline Sep-12 & 8 & $0.076-0.236$ & $0.140 \pm 0.052$ & 7 & $0.055-0.112$ & $0.086 \pm 0.022$ & 14 & $0.036-0.076$ & $0.052 \pm 0.012$ \\
\hline Jun-13 & 12 & $0.031-0.392$ & $0.188 \pm 0.116$ & 6 & $0.035-0.073$ & $0.052 \pm 0.014$ & 25 & $0.010-0.099$ & $0.039 \pm 0.021$ \\
\hline All cruises & 47 & $0.016-0.392$ & $0.110 \pm 0.086$ & 33 & $0.012-0.128$ & $0.058 \pm 0.030$ & 70 & $0.006-0.099$ & $0.039 \pm 0.023$ \\
\hline \multicolumn{10}{|l|}{$a_{d}(440)\left(m^{-1}\right)$} \\
\hline Jun-08 & 7 & $0.059-0.282$ & $0.142 \pm 0.083$ & 3 & $0.041-0.064$ & $0.056 \pm 0.012$ & 5 & $0.006-0.062$ & $0.043 \pm 0.025$ \\
\hline Jun-10 & 4 & $0.003-0.025$ & $0.011 \pm 0.010$ & 7 & $0.001-0.005$ & $0.003 \pm 0.001$ & 16 & $0.0001-0.007$ & $0.002 \pm 0.002$ \\
\hline Mar-11 & 10 & $0.007-0.061$ & $0.038 \pm 0.015$ & 9 & $0.013-0.032$ & $0.021 \pm 0.007$ & 8 & $0.006-0.024$ & $0.014 \pm 0.007$ \\
\hline Aug-12 & 6 & $0.092-0.433$ & $0.256 \pm 0.114$ & 1 & 0.045 & 0.045 & 2 & $0.012-0.014$ & $0.013 \pm 0.001$ \\
\hline Sep-12 & 8 & $0.126-0.762$ & $0.290 \pm 0.206$ & 7 & $0.019-0.062$ & $0.037 \pm 0.015$ & 14 & $0.007-0.039$ & $0.015 \pm 0.011$ \\
\hline Jun-13 & 12 & $0.059-2.257$ & $0.904 \pm 0.802$ & 6 & $0.015-0.144$ & $0.057 \pm 0.046$ & 25 & $0.002-0.105$ & $0.018 \pm 0.024$ \\
\hline All cruises & 47 & $0.003-2.257$ & $0.343 \pm 0.531$ & 33 & $0.001-0.144$ & $0.031 \pm 0.028$ & 70 & $0.0001-0.105$ & $0.015 \pm 0.019$ \\
\hline \multicolumn{10}{|c|}{$\mathrm{a}_{\mathrm{CDOM}}(440)\left(\mathrm{m}^{-1}\right)$} \\
\hline Jun-08 & - & - & - & - & - & - & - & - & - \\
\hline Jun-10 & - & - & - & - & - & - & - & - & - \\
\hline Mar- 11 & 7 & $0.053-0.146$ & $0.098 \pm 0.036$ & 6 & $0.030-0.421$ & $0.161 \pm 0.157$ & 8 & $0.028-0.213$ & $0.090 \pm 0.066$ \\
\hline Aug-12 & 5 & $0.017-0.178$ & $0.129 \pm 0.065$ & 1 & 0.064 & 0.064 & 2 & $0.232-0.258$ & $0.245 \pm 0.018$ \\
\hline Sep-12 & 9 & $0.058-0.210$ & $0.118 \pm 0.042$ & 5 & $0.039-0.083$ & $0.059 \pm 0.018$ & 11 & $0.009-0.047$ & $0.026 \pm 0.012$ \\
\hline Jun-13 & 10 & $0.110-0.388$ & $0.194 \pm 0.078$ & 1 & 0.009 & 0.009 & 8 & $0.004-0.245$ & $0.070 \pm 0.096$ \\
\hline All cruises & 31 & $0.017-0.388$ & $0.140 \pm 0.068$ & 13 & $0.009-0.421$ & $0.103 \pm 0.117$ & 29 & $0.004-0.258$ & $0.071 \pm 0.081$ \\
\hline \multicolumn{10}{|l|}{$\mathrm{Chla}\left(\mathrm{mg} / \mathrm{m}^{3}\right)$} \\
\hline Jun-08 & 7 & $0.83-2.03$ & $1.51 \pm 0.50$ & 3 & $0.67-3.28$ & $1.90 \pm 1.31$ & 5 & $0.62-1.15$ & $0.81 \pm 0.22$ \\
\hline Jun-10 & 4 & $0.42-3.33$ & $1.34 \pm 1.35$ & 9 & $0.24-1.17$ & $0.62 \pm 0.31$ & 15 & $0.12-2.45$ & $0.43 \pm 0.58$ \\
\hline Mar-11 & 10 & $0.77-4.11$ & $2.07 \pm 1.18$ & 9 & $0.48-6.88$ & $2.19 \pm 2.16$ & 8 & $0.60-2.61$ & $1.37 \pm 0.63$ \\
\hline Aug-12 & 4 & $0.86-3.52$ & $1.69 \pm 1.25$ & 1 & 0.65 & 0.65 & 2 & $0.32-0.77$ & $0.54 \pm 0.32$ \\
\hline Sep-12 & - & - & - & - & - & - & - & - & - \\
\hline Jun-13 & 15 & $0.53-4.44$ & $2.26 \pm 1.22$ & 5 & $0.34-0.94$ & $0.51 \pm 0.25$ & 25 & $0.08-0.87$ & $0.31 \pm 0.21$ \\
\hline All cruises & 40 & $0.42-4.44$ & $1.93 \pm 1.13$ & 27 & $0.24-6.88$ & $1.27 \pm 1.5$ & 55 & $0.08-2.61$ & $0.55 \pm 0.55$ \\
\hline
\end{tabular}


Some phytoplankton pigments can be used as markers for certain algal groups [37]. This work used pigments for assessing the composition of the phytoplankton community according to Table 3 [37]. June 2008 (Figure 5(a)) showed a high proportion (70\%) of fucoxanthin (indicator of diatoms) in UGC, but an increase in the percentage of peridinin (dinoflagellates), 19'Hex (prymnesiophytes) and zeaxanthin (cyanobacteria) in the transition zone and NGC region.

June 2010 (Figure 5(b)) again showed a high proportion of fucoxanthin in UGC, but with a greater participation of 19'Hex and 19'But (crysophytes and prymnesiophytes). The transition zone showed a rise in the contribution of zeaxanthin (30\%) and 19'But, while pigments with a larger proportion in NGC are zeaxanthin, fucoxanthin and $19^{\prime} \mathrm{Hex}$, the latter with $>35 \%$ in some stations. In March 2011 (Figure 5(c)), fucoxanthin and peridinin in general contributed more than $70 \%$ to total pigments in all regions. It should be noted that alloxanthin, a marker pigment for cryptophytes (Table 3), was recorded in all stations in spite of a contribution lower than $5 \%$ in some of them. This pigment was not observed in June 2008, and was recorded in a few stations in June 2010. In August 2012 (Figure 5(d)), a cruise that included few stations, a significant change was observed in the proportion of pigments, with a high contribution of chlorophyll b (>45\%), followed by fucoxanthin and zeaxanthin, but with a higher proportion of fucoxanthin (36\%) in UGC and an increase in zeaxanthin (>30\%) in the transition zone and NGC region.

Finally, June 2013 (Figure 5(e)) showed a continued predominance of fucoxanthin and chlorophyll $b$ in UGC, and of zeaxanthin and chlorophyll $\mathrm{b}$ in NGC, with some stations where fucoxanthin was also observed. In turn, the transition zone showed a fairly homogeneous participation of the three pigments, i.e. fucoxanthin, zeaxanthin and chlorophyll $b$.

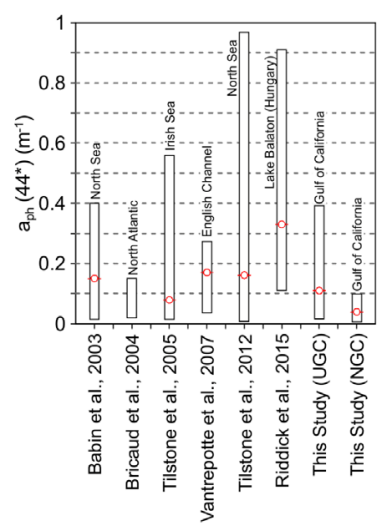

(a)

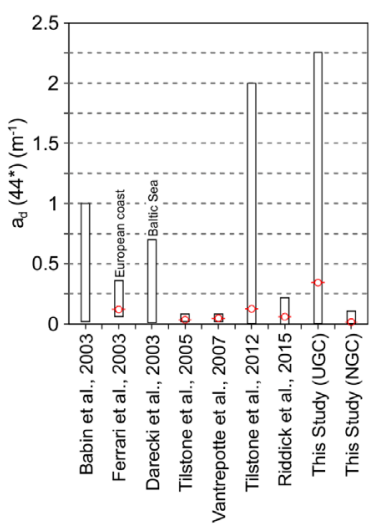

(b)

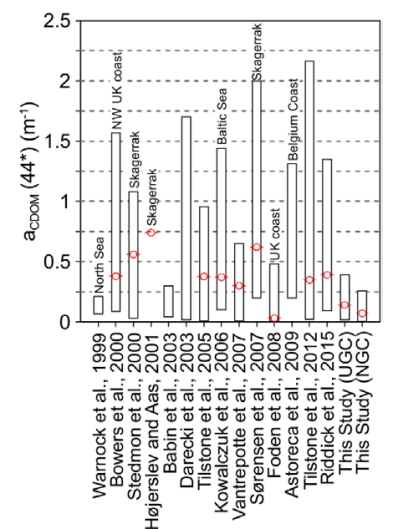

(c)

Figure 4. Average (red circle) and minimum and maximum (rectangle) values for (a) $a_{p h}$, (b) $\mathrm{a}_{\mathrm{d}} \mathrm{y}$ (c) $\mathrm{a}_{\mathrm{CDOM}}$ from data in this study and others (data taken from Tilstone et al., [39]). The asterisk in the y-axes indicates that values can be for 440, 442 or $443 \mathrm{~nm}$ depending on the data base. Data from this study are for $440 \mathrm{~nm}$. 


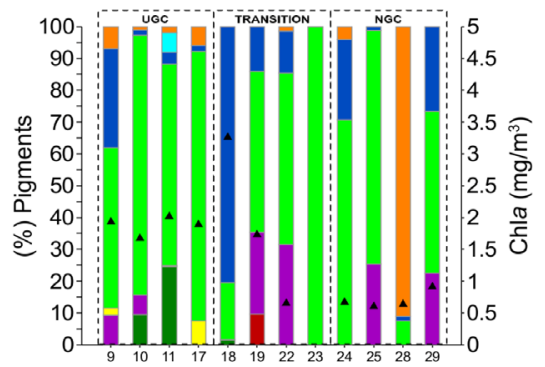

(a)

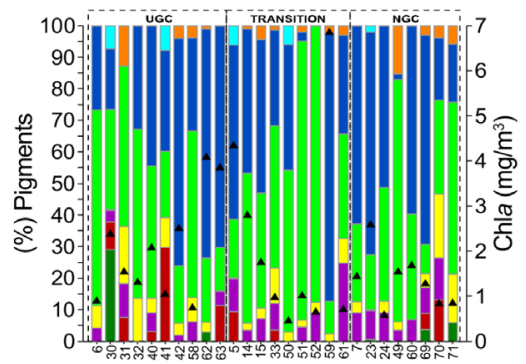

(c)

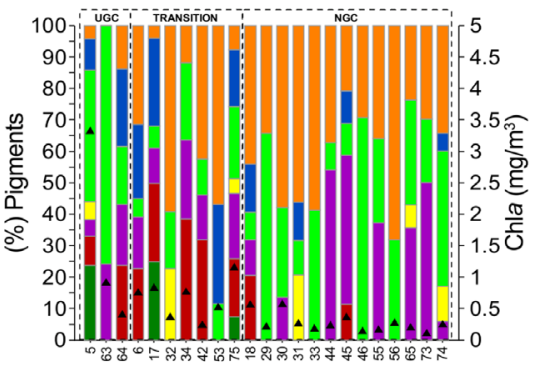

(b)

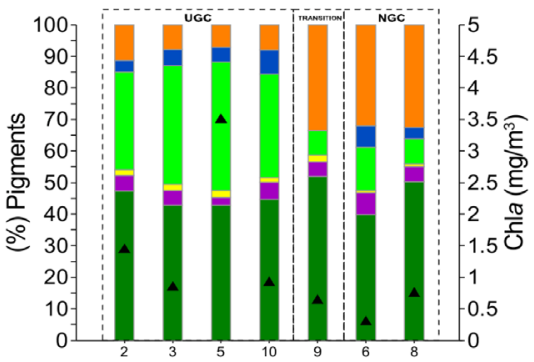

(d)

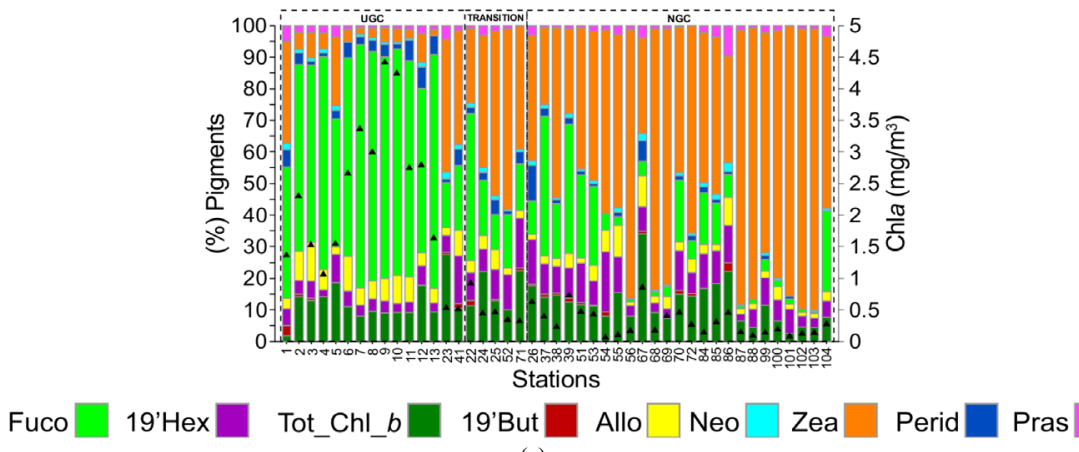

(e)

Figure 5. Vertical bars represent the percent contribution of each pigment by station (left axis); colors correspond to pigments listed in the legend. Black triangles correspond to Chla concentration $\left(\mathrm{mg} / \mathrm{m}^{3}\right.$ ) (right axis). Dotted black lines delimit the bio-optical regions (UGC: Upper Gulf of California; NGC: North Gulf of California; Transition: Transition zone). Separate graphs are shown for (a) June 2008, (b) June 2010, (c) March 2011, (d), August 2012, and (e) June 2013.

Table 3. Phytoplankton pigments recorded in study samples useful as diagnostic markers (adapted from Jeffrey et al. [37]).

\begin{tabular}{ccc}
\hline PIGMENT & ABBREVIATION & ALGAL GROUPS \\
\hline Total Chlorophyll $a$ & {$[$ Tot_Chl_a $]$} & All groups except Prochlorococcus \\
Total Chlorophyll $b$ & {$[$ Tot_Chl_b $]$} & Chlorophytes, Prasinophytes, Euglenophytes \\
19 '-Butanoyloxyfucoxanthin & {$\left[19^{\prime}\right.$ But $]$} & Chrysophytes, Prymnesiophytes \\
$19 '$-Hexanoyloxyfucoxanthin & {$\left[19^{\prime} \mathrm{Hex}\right]$} & Prymnesiophytes \\
Alloxa. nthin & {$[$ Allo $]$} & Cryptophytes \\
Fucoxanthin & {$[$ Fuco $]$} & Diatoms, Prymnesiophytes, Chrysophytes, Raphidophytes \\
Peridinin & {$[$ Perid $]$} & Dinoflagellates \\
Zeaxanthin & {$[$ Zea $]$} & Cyanobacteria (including Prochlorococcus), Rhodophytes, Chlorophytes, Estigmatophytes \\
Neoxanthin & {$[\mathrm{Neo}]$} & Chlorophytes, Prasinophytes \\
Prasinoxanthin & {$[$ Pras $]$} & Prasinophytes \\
\hline
\end{tabular}




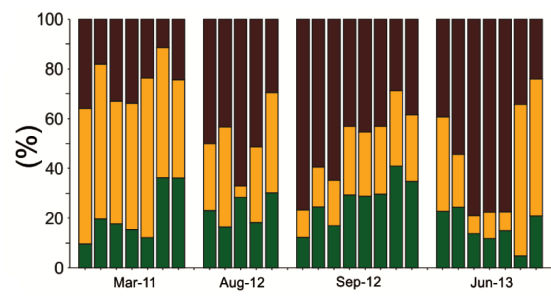

(a)

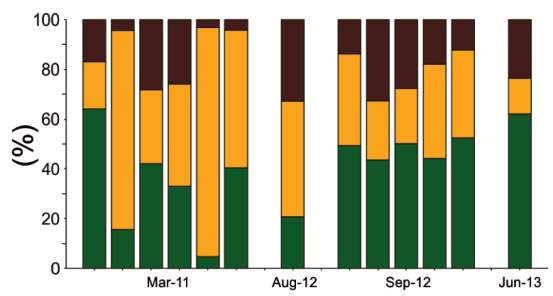

(c)

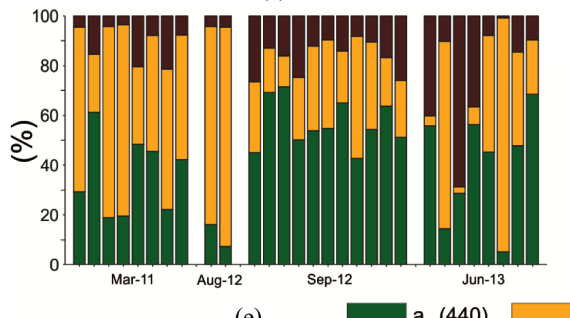

(e)

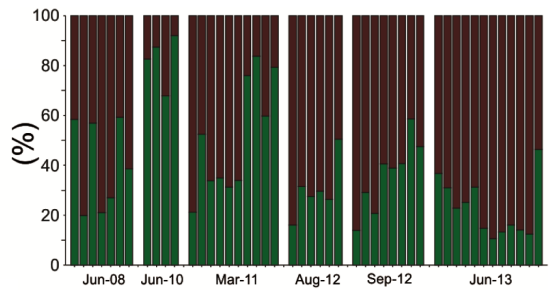

(b)
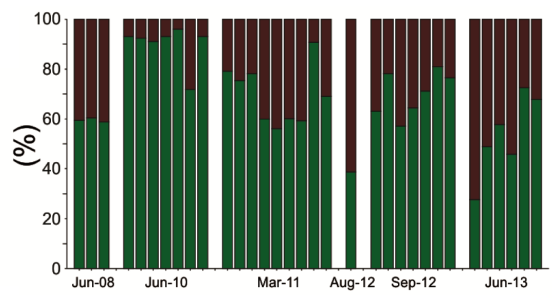

(d)

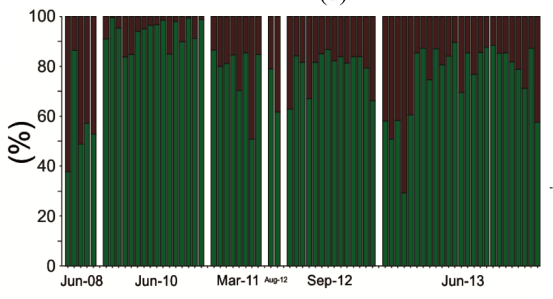

(f)

Figure 6. Contribution of $\mathrm{a}_{\mathrm{ph}}(440), \mathrm{a}_{\mathrm{d}}(440)$ and $\mathrm{a}_{\mathrm{CDOM}}(440)$ to light absorption in March 2011, August and September 2012, and June 2013 for (a) UGC; (b) Transition and (c) NGC; and contribution to light absorption by $\mathrm{a}_{\mathrm{ph}}(440)$ and $\mathrm{a}_{\mathrm{d}}(440)$ in all cruises for $(\mathrm{d})$ UGC; (e) Transition and (f) NGC.

\subsection{Absorption Budget}

The relative contribution of the absorption coefficients, $a_{p h}(440), a_{d}(440)$ and $a_{\mathrm{CDOM}}(440)$ to total light absorption was explored for the March 2011, August and September 2012 and June 2013 cruises (Figures 6(a)-(c)). Considering that for June 2008 and 2010 no $a_{\mathrm{CDOM}}(440)$ data were obtained we evaluated the relative contribution of only $a_{d}(440)$ and $a_{p h}(440)$ for all cruises for comparison (Figures 6(d)-(f)).

In UGC the high contribution of $a_{d}(440)$ for light absorption is evident with an increasing trend from March 2011 to June 2013 (Figure 6(a)). This increase was followed by a decrease in $a_{\mathrm{CDOM}}(440)$ while $a_{p h}(440)$ had almost no variability with a contribution from 10 to $40 \%$ to total light absorption. When this analysis took in account the contribution of only $a_{p h}(440)$ and $a_{d}(440)$ (Figure 6(b)) the importance of detritus is emphasized and $a_{d}(440)$ was most of the time higher than $40 \%$ reaching $80 \%$ in June 2013. An exception was observed in June 2010 although this cruise was also the one with the lowest number of stations in this region.

The contribution of $a_{d}(440)$ to light absorption at NGC is much lower than in UGC while the average contribution of $a_{p h}(440)$ is much higher (Figure 6(c) Figure $6(\mathrm{f})$ ). In the analysis based on the cruises with $a_{\mathrm{CDOM}}(440)$ data (Figure $6(c))$ it was possible to observe that the contribution of this component can be 
even higher than $a_{p h}(440)$ depending on the cruise as it was for most stations in March 2012, August 2012 and June 2013, while in September $2012 a_{p h}(440)$ contribution was always higher than $40 \%$. When this analysis was carried out considering only $a_{p h}(440)$ and $a_{d}(440)$ (Figure 6(f)), $a_{p h}(440)$ appears as the most important component with an average contribution of $79 \%$. The transition zone (Figure 6(b)(e)) has similar characteristics to those of NGC with a co-dominium by $a_{p h}(440)$ and $a_{\mathrm{CDOM}}(440)$ ( $40 \%$ and $41 \%$ in average) (Figure $6(\mathrm{~b})$ ) while $a_{p h}(440)$ had a contribution of more than $60 \%$ when $a_{\text {CDOM }}(440)$ is not taken into consideration (Figure 6(e)).

\section{Discussion}

The spatial and temporal variability of light absorption properties has been used as a successful tool for coastal water research and management [40] and classification schemes has been recommended to integrate optics into ecological studies [41]. However, the measurement of these variables through remote sensing can be challenging in coastal waters, especially those associated to strong spatial gradients. Our results indicate that at the northern Gulf of California this variability is high although a spatial pattern is observed that allowed the definition of two bio-optical regions. Nevertheless, their spatial distribution changes in time what was emphasized through the analysis of the transition zone, which position is probably related to a tidal-mixing front, responsible for the resuspension of sediments and the separation between the well-mixed waters in UGC and the deep and stratified waters in NGC [19]. Although the average location of the transition zone is consistent with previous works [18] [26] there are obvious differences between cruises, associated with differences in the physical conditions during each one. For example, March 2011 showed a pattern that was markedly different from the one in all others cruises, with UGC located off Baja California peninsula while the transition zone was located to the south. This pattern matches the seasonal transition period described by Montes et al. [42], characterized by the simultaneous presence of cyclonic and anti-cyclonic eddies. Despite the temporal changes in the spatial distribution of each bio-optical region they maintained particular characteristic that will be useful on future approaches for the remote sensing of the light absorption properties.

In general, UGC showed the highest Chla levels and the highest contribution by fucoxanthin (Figure 5), pigment that indicates the presence of diatoms (Table 3), a group associated with areas of high nutrient concentrations and vertical mixing [43]. Santamaría-del-Ángel et al. [44] noted that this group may show high productivity rates despite low light penetration associated with high turbidity in this region through the increase in Chla per cell. In March 2011 peridinin also had an important contribution, indicating the presence of dinoflagellates. Diatoms and dinoflagellates are phytoplankton groups that in general belong to microphytoplankton [45], size class associated to high nutrient concentrations. Another important feature of this region is the largest contribution 
of $\mathrm{a}_{\mathrm{d}}(\lambda)$ and in occasion $\mathrm{a}_{\mathrm{CDOM}}(\lambda)$ to total light absorption irrespective of the marked temporal variability in the relative contribution of each component (Figure 6). The distinctive optical characteristics of UGC were highlighted by Bastidas-Salamanca et al. [18] when working with data from June 2008, as they observed a significant negative correlation between the light attenuation coefficient $\left(\mathrm{K}_{\mathrm{d}}\right)$ and Chla, associated with the high concentration of mineral particles in the area. The authors suggested that the equation derived from their analysis could be used for modelling the relationship between these variables. Meanwhile, the data analyzed in this study did not show the same trend, highlighting the important temporal variability in the area. On the other hand, a fact that should be kept in mind is that most cruises sampled a few stations in UGC, and given the variability observed, a greater sampling effort should be conducted in this area in order to properly evaluate the optical variability in it.

The comparison of our data with those from other regions (Figure 4) allowed us to infer the importance of $a_{d}(440)$ to the optical properties of UGC. While $\mathrm{a}_{\mathrm{ph}}(440)$ and $\mathrm{a}_{\mathrm{CDOM}}(440)$ were in the same range of variability than in other regions, $a_{d}(440)$ was much higher and with a larger range of variability (0.003 to $2.26 \mathrm{~m}^{-1}$ ) what also may indicate that this particular characteristic should be taken in account for an accurate use of bio-optical models. Moreover, NGC region is more oligotrophic than UGC, showing the lowest values of $\mathrm{Chl} a, \mathrm{a}_{\mathrm{ph}}(\lambda)$ and $\mathrm{a}_{\mathrm{d}}(\lambda)$ (Table 2) in spite of a high contribution by $\mathrm{a}_{\mathrm{CDOM}}(\lambda)$ (Figure $6(\mathrm{c})$ ) in many stations.

The pigment composition at NGC revealed a high predominance of zeaxanthin and occasionally Chlorophyll b, indicating the importance of cyanobacteria and green algae. These phytoplankton groups belong to the picoplankton size fractions which are characteristics of nutrient-poor waters [46] what also explains the differences with UGC. March 2011 was an exception, as the contribution of fucoxanthin and peridinin spread across the entire study area. This pattern can be associated to the above mentioned spring conditions, which promote phytoplankton blooms in the gulf due to the increase in irradiance levels [47]. In fact, data analyzed in another study [48] showed primary production rates up to six times as high in March 2011 as those recorded in June 2010.

The study region is a water body with a strong optical complexity that was previously classified as Case II waters [17] although Bastidas-Salamanca et al. [18] mentioned that this assumption is a simplification given the differences observed in the optical properties between UGC and NGC. The area covered by the study region is smaller than other coastal waters such as the North Sea or the Baltic Sea, but its optical characteristics are spatially more variable. For example, and as previously mentioned, average $\mathrm{a}_{\mathrm{ph}}(440)$ and $\mathrm{a}_{\mathrm{CDOM}}(440)$ at UGC were below those values observed in other regions (Figure 4). However, ad(440) was not only highly variable ( 0.003 to $\left.2.257 \mathrm{~m}^{-1}\right)$, but it was also much higher. The analysis of the proportional contribution of each component to light absorption (Figure 6) indicated both the differences between UGC and NGC and the importance of detritus in UGC and CDOM in NGC. 


\section{Conclusion}

This work makes a major contribution to the knowledge of the bio-optical properties in optically complex waters such as those to the north of the Gulf of California, a region characterized by a strong hydrodynamic reflected in a marked spatial and temporal variability of their bio-optical properties, including the composition of primary producers. More specifically, our study confirmed the presence of two bio-optical regions (UGC and NGC), which particular characteristics emphasizes that Case II waters can be very different when evaluating the individual contribution by phytoplankton, detritus and CDOM to total light absorption. Particularly, UGC region was characterized by a stronger contribution by detritus while at NGC phytoplankton and CDOM alternate their dominance. One important application of this classification is the selection of bio-optical models for each specific region taking in account their particular characteristics, what can also help to a better definition of the related uncertainties.

\section{Acknowledgements}

The first author was supported by CONACyT (Mexican Council of Science) through a $\mathrm{PhD}$ scholarship (No. 384224). This work was funded by projects SIMAC-CONACYT, SIMAC-2000107017; CICESE: Ecological monitoring of the Upper Gulf of California" (PANGAS-Packard Foundation); IPN-CICIMAR: SIP 1721, 20160514-CONACYT: 236864. Cruises were supported by the Mexican Navy (Secretariat of the Navy) and R/V Francisco de Ulloa (CICESE). We thank all the students from the Phytoplankton Ecology Team of the Faculty of Marine Science that participated in cruises and sampling procedures. We gratefully acknowledge the comments, suggestions and English edition of María Elena Sánchez-Salazar and anonymous reviewers.

\section{References}

[1] Garver, S.A. and Siegel, D.A. (1997) Inherent Optical Property Inversion of Ocean Color Spectra and Its Biogeochemical Interpretation: 1. Time Series from the Sargasso Sea. Journal of Geophysical Research: Oceans, 102, 18607-18625. https://doi.org/10.1029/96JC03243

[2] Lee, Z., Carder, K.L., Steward, R.G., Peacock, T.G., Davis, C.O. and Patch, J.S. (1998) An Empirical Algorithm for Light Absorption by Ocean Water Based on Color. Journal of Geophysical Research: Oceans, 103, 27967-27978. https://doi.org/10.1029/98JC01946

[3] Carder, K.L., Chen, F.R., Lee, Z.P., Hawes, S.K. and Kamykowski, D. (1999) Semianalytic Moderate-Resolution Imaging Spectrometer Algorithms for Chlorophyll a and Absorption with Bio-Optical Domains Based on Nitrate-Depletion Temperatures. Journal of Geophysical Research: Oceans, 104, 5403-5421. https://doi.org/10.1029/1998JC900082

[4] Morel, A. and Prieur, L. (1977) Analysis of Variations in Ocean Color. Limnology and Oceanography, 22, 709-722. https://doi.org/10.4319/lo.1977.22.4.0709

[5] IOCCG (2000) Remote Sensing of Ocean Colour in Coastal, and Other Optically-Complex, Waters. In: Sathyendranath, S., Ed., Reports of the International 
Ocean-Colour Coordinating Group, No. 3, IOCCG, Dartmouth.

[6] Ferreira, A., Ciotti, Á.M. and Giannini, M.F.C. (2014) Variability in the Light Absorption Coefficients of Phytoplankton, Non-Algal Particles, and Colored Dissolved Organic Matter in a Subtropical Bay (Brazil). Estuarine, Coastal and Shelf Science, 139, 127-136. https://doi.org/10.1016/j.ecss.2014.01.002

[7] Lee, Z., Carder, K.L. and Arnone, R.A. (2002) Deriving Inherent Optical Properties from Water Color: A Multiband Quasi-Analytical Algorithm for Optically Deep Waters. Applied Optics, 41, 5755-5772. https://doi.org/10.1364/AO.41.005755

[8] Maritorena, S., Siegel, D.A. and Peterson, A.R. (2002) Optimization of a Semianalytical Ocean Color Model for Global-Scale Applications. Applied Optics, 41, 2705-2714. https://doi.org/10.1364/AO.41.002705

[9] Franz, B.A. and Werdell, P.J. (2010) A Generalized Framework for Modeling of Inherent Optical Properties in Ocean Remote Sensing Applications. Proceedings of Ocean Optics, Anchorage, Alaska, 27, 1-13.

[10] Werdell, P.J., Franz, B.A., Bailey, S.W., Feldman, G.C., Boss, E., Brando, V.E., Loisel, H., et al. (2013) Generalized Ocean Color Inversion Model for Retrieving Marine Inherent Optical Properties. Applied Optics, 52, 2019-2037. https://doi.org/10.1364/AO.52.002019

[11] Siegel, D.A., Maritorena, S., Nelson, N.B., Hansell, D.A. and Lorenzi-Kayser, M. (2002) Global Distribution and Dynamics of Colored Dissolved and Detrital Organic Materials. Journal of Geophysical Research: Oceans, 107, 3228.

[12] Blough, N.V. and Del Vecchio, R. (2002) Chromophoric DOM in the Coastal Environment. In: Hansell, D.A. and Carlson, C.A., Eds., Biogeochemistry of Marine Dissolved Organic Matter, Academic Press, San Diego, 509-546. https://doi.org/10.1016/B978-012323841-2/50012-9

[13] Nelson, N.B. and Siegel, D.A. (2002) Chromophoric DOM in the Open Ocean. Biogeochemistry of Marine Dissolved Organic Matter, 2002, 547-554, cp1-cp2, 555-578. https://doi.org/10.1016/B978-012323841-2/50013-0

[14] Brezonik, P.L., Olmanson, L.G., Finlay, J.C. and Bauer, M.E. (2015) Factors Affecting the Measurement of CDOM by Remote Sensing of Optically Complex Inland Waters. Remote Sensing of Environment, 157, 199-215. https://doi.org/10.1016/j.rse.2014.04.033

[15] IOCCG (2006) Remote Sensing of Inherent Optical Properties: Fundamentals, Tests of Algorithms, and Applications. In: Lee, Z.-P., Ed., Reports of the International Ocean-Colour Coordinating Group, No. 5, IOCCG, Dartmouth.

[16] Roesler, C.S., Perry, M.J. and Carder, K.L. (1989) Modeling in Situ Phytoplankton Absorption from Total Absorption Spectra in Productive Inland Marine Waters. Limnology and Oceanography, 34, 1510-1523. https://doi.org/10.4319/lo.1989.34.8.1510

[17] Pegau, W.S., Zaneveld, J.R.V., Barnard, A.H., Maske, H., Álvarez Borrego, S., Lara Lara, R. and Cervantes Duarte, R. (1999) Inherent Optical Properties in the Gulf of California. Ciencias Marinas, 25, 469-485.

http://www.redalyc.org/articulo.oa?id=48025402 https://doi.org/10.7773/cm.v25i4.731

[18] Bastidas-Salamanca, M., Gonzalez-Silvera, A., Millán-Núñez, R., Santamaria-delAngel, E. and Frouin, R. (2014) Bio-Optical Characteristics of the Northern Gulf of California during June 2008. International Journal of Oceanography, 2014, Article ID: 384618. https://doi.org/10.1155/2014/384618 
[19] Argote, M.L., Amador, A., Lavín, M.F. and Hunter, J.R. (1995) Tidal Dissipation and Stratification in the Gulf of California. Journal of Geophysical Research: Oceans, 100, 16103-16118. https://doi.org/10.1029/95JC01500

[20] Sanchez-Velasco, L., Lavín, M.F., Peguero-Icaza, M., León-Chávez, C.A., Contreras-Catala, F., Marinone, S.G., Godínez, V.M., et al. (2009) Seasonal Changes in Larval Fish Assemblages in a Semi-Enclosed Sea (Gulf of California). Continental Shelf Research, 29, 1697-1710. https://doi.org/10.1016/j.csr.2009.06.001

[21] Santamaría-del-Angel, E., Alvarez-Borrego, S. and Müller-Karger, F.E. (1994) Gulf of California Biogeographic Regions Based on Coastal Zone Color Scanner Imagery. Journal of Geophysical Research: Oceans, 99, 7411-7421. https://doi.org/10.1029/93JC02154

[22] Hidalgo-Gonzalez, R.M. and Alvarez-Borrego, S. (2001) Chlorophyll Profiles and the Water Column Structure in the Gulf of California. Oceanologicaacta, 24, 19-28. https://doi.org/10.1016/S0399-1784(00)01126-9

[23] Millan-Nuez, E., Lara-Lara, J.R. and Cleveland, J.S. (1998) Variations in Specific Absorption Coefficients and Total Phytoplankton in the Gulf of California. California Cooperative Oceanic Fisheries Investigations Report, 159-168.

[24] Brewin, R.J., Sathyendranath, S., Müller, D., Brockmann, C., Deschamps, P.Y., Devred, E. and Groom, S. (2015) The Ocean Colour Climate Change Initiative: III. A Round-Robin Comparison on In-Water Bio-Optical Algorithms. Remote Sensing of Environment, 162, 271-294. https://doi.org/10.1016/j.rse.2013.09.016

[25] Coble, P.G. (2007) Marine Optical Biogeochemistry: The Chemistry of Ocean Color. Chemical Reviews, 107, 402-418. https://doi.org/10.1021/cr050350+

[26] Lavín, M.F. and Marinone, S.G. (2003) An Overview of the Physical Oceanography of the Gulf of California. In: Nonlinear Processes in Geophysical Fluid Dynamics, Springer, Berlin, 173-204. https://doi.org/10.1007/978-94-010-0074-1_11

[27] Borrego, S.A., Báez, B.P.F. and Bect, L.A.G. (1975) Hidrología del Alto Golfo de California II. Condiciones duranteinvierno primavera y verano. Ciencias Marinas, 2, 21-36. https://doi.org/10.7773/cm.v2i1.275

[28] Alvarez-Borrego, S. and Galindo-Bect, L.A. (1974) Hidrológia del Alto Golfo de California-I. Condiciones Durante Otoño. Ciencias Marinas, 1, 46-64.

https://doi.org/10.7773/cm.v1i1.248

[29] Lavın, M.F., Godınez, V.M. and Alvarez, L.G. (1998) Inverse-Estuarine Features of the Upper Gulf of California. Estuarine, Coastal and Shelf Science, 47, 769-795. https://doi.org/10.1006/ecss.1998.0387

[30] Lavín, M.F. and Organista, S. (1988) Surface Heat Flux in the Northern Gulf of California. Journal of Geophysical Research: Oceans, 93, 14033-14038. https://doi.org/10.1029/JC093iC11p14033

[31] Lavin, M.F. and Sánchez, S. (1999) On How the Colorado River Affected the Hydrography of the Upper Gulf of California. Continental Shelf Research, 19, 1545-1560. https://doi.org/10.1016/S0278-4343(99)00030-8

[32] Santamaría-del-Ángel, E., Soto, I., Millán-Nuñez, R., González-Silvera, A., Wolny, J., Cerdeira-Estrada, S., Cajal-Medrano, R., Muller-Karger, F., Cannizzaro, J., Padilla-Rosas, Y.X.S., Mercado-Santana, A., Gracia-Escobar, M.F., Álvarez-Torres, P. and Ruiz-de-la-Torre, M.C. (2015) Phytoplankton Blooms: New Initiative using Marine Optics as a Basis for Monitoring Programs. In: Sebastia-Frasquet, M.-T., Ed., Coastal Ecosystems. Experiences and Recommendations for Environmental Monitoring Programs, Nova Science Publishers, 32. 
[33] Kirk, J.T.O. (1994) Light and Photosynthesis in Aquatic Ecosystems. Cambridge University Press, Cambridge, 509 p. https://doi.org/10.1017/CBO9780511623370

[34] Mitchell, B.G., Kahru, M., Wieland, J., Stramska, M. and Mueller, J.L. (2002) Determination of Spectral Absorption Coefficients of Particles, Dissolved Material and Phytoplankton for Discrete Water Samples. Ocean Optics Protocols for Satellite Ocean Color Sensor Validation. Revision, 3, 231-257.

[35] Barlow, R.G., Cummings, D.G. and Gibb, S.W. (1997) Improved Resolution of Mono- and Divinyl Chlorophylls a and b and Zeaxanthin and Lutein in Phytoplankton Extracts using Reverse Phase C-8 HPLC. Marine Ecology Progress Series, 161, 303-307. https://doi.org/10.3354/meps161303

[36] Thomas, C. (2012) The HPLC Method. In: The 5th SeaWiFS HPLC Analysis Round-Robin Experiment, Chapter 6, Buscar Con Google, 63-72.

[37] Jeffrey, S.W., Mantoura, R.F.C. and Wright, S.W. (1997) Phytoplankton Pigments in Oceanography: Guidelines to Modern Methods (Monographs on Oceanographic Methodology).

[38] Zar, J.H. (1999) Biostatistical Analysis. Pearson Education India.

[39] Tilstone, G.H., Peters, S.W., van der Woerd, H.J., Eleveld, M.A., Ruddick, K., Schönfeld, W., Sørensen, K., et al. (2012) Variability in Specific-Absorption Properties and Their Use in a Semi-Analytical Ocean Colour Algorithm for MERIS in North Sea and Western English Channel Coastal Waters. Remote Sensing of Environment, 118, 320-338. https://doi.org/10.1016/j.rse.2011.11.019

[40] Werdell, P.J., Franz, B.A., Bailey, S.W., Harding Jr, L.W. and Feldman, G.C. (2007) Approach for the Long-Term Spatial and Temporal Evaluation of Ocean Color Satellite Data Products in a Coastal Environment. Proceedings of SPIE, 6680, 66800G. https://doi.org/10.1117/12.732489

[41] Mélin, F. and Vantrepotte, V. (2015) How Optically Diverse Is the Coastal Ocean? Remote Sensing of Environment, 160, 235-251. https://doi.org/10.1016/j.rse.2015.01.023

[42] Montes, J.M., Lavín, M.F. and Parés-Sierra, A.F. (2015) Seasonal Heat and Salt Balance in the Upper Gulf of California. Journal of Coastal Research, 32, 853-862.

[43] Sarthou, G., Timmermans, K.R., Blain, S. and Tréguer, P. (2005) Growth Physiology and Fate of Diatoms in the Ocean: A Review. Journal of Sea Research, 53, 25-42. https://doi.org/10.1016/j.seares.2004.01.007

[44] Santamaría-del-Ángel, E., Millán-Núñez, R. and De la Peña-Nettel, G. (1996) Efecto de la turbidez en la productividad primaria en dos estaciones en el área del delta del Río Colorado. Ciencias Marinas, 22, 483-493.

[45] Uitz, J., Claustre, H., Morel, A. and Hooker, S.B. (2006) Vertical Distribution of Phytoplankton Communities in Open Ocean: An Assessment Based on Surface Chlorophyll. Journal of Geophysical Research: Oceans, 111, C08005.

[46] Ji, Z.G. (2008) Hydrodynamics and Water Quality: Modeling Rivers, Lakes, and Estuaries. John Wiley and Sons. https://doi.org/10.1002/9780470241066

[47] Gaxiola-Castro, G., Alvarez-Borrego, S., Lavín, M.F., Zirino, A. and Nájera-Martínez, S. (1999) Spatial Variability of the Photosynthetic Parameters and Biomass of the Gulf of California Phytoplankton. Journal of Plankton Research, 21, 231-245. https://doi.org/10.1093/plankt/21.2.231

[48] Gracia-Escobar, M.F. (2016) Abundancia, Carbono: Clorofila a, Productividad Primaria, Pigmentos y absorción de la luz del fitoplancton en el Alto Golfo de California. Ph.D. Thesis, Universidad Autónoma de Baja California, Ensenada, Baja California, México. 